\section{Characterization of epidemiological surveillance systems for healthcare-associated infections (HAI) in the world and challenges for Brazil}

\author{
Caracterização dos sistemas de vigilância \\ epidemiológica das infecções relacionadas \\ à assistência à saúde (IRAS) no mundo \\ e desafios para o Brasil
}

\author{
${ }^{1}$ Escola de Enfermagem, \\ Universidade de São Paulo \\ São Paulo, Brasil. \\ 2 Hospital das Clínicas, \\ Universidade de São Paulo, \\ São Paulo, Brasil. \\ 3 Faculdade de Medicina, \\ Universidade de São Paulo, \\ São Paulo, Brasil. \\ Correspondence \\ C. Nogueira Junior \\ Escola de Enfermagem, \\ Universidade de São Paulo. \\ Rua Francisco Bueno Lacerda \\ 220, apto. 113, bloco A, \\ Campinas, $S P$ \\ 13036-265, Brasil. \\ cassimiro_ufjf@yahoo.com.br
}

\begin{abstract}
Surveillance systems for healthcare-associated infections (HAI) are essential for planning actions in prevention and control. Important models have been deployed in recent decades in different countries. This study aims to present the historical and operational characteristics of these systems and discuss the challenges for Brazil. Various models around the world have drawn on the experience of the United States, which pioneered this process. In Brazil, several initiatives have been launched, but the country still lacks a full national information system on HAI, thus indicating the need to promote action strategies, strengthen the role of States in communication between the Federal and local levels, pursue a national plan to organize surveillance teams with the necessary technological infrastructure, besides updating the relevant legislation for dealing with these challenges. Such measures are essential in the Brazilian context for the unified surveillance of HAI, aimed at healthcare safety and quality.
\end{abstract}

Cross Infection; Infection Control; Epidemiological Surveillanec; Information Systems
Cassimiro Nogueira Junior 1

Débora Silva de Mello 1

Maria Clara Padoveze 1

Icaro Boszczowski 2

Anna Sara Levin 3

Rubia Aparecida Lacerda ${ }^{1}$

\section{Resumo}

A formação de sistemas de vigilância de infecções relacionadas à assistência à saúde (IRAS) é medida essencial para o planejamento de ações de prevenção e controle. No mundo, importantes modelos estão sendo implantados nas últimas décadas. Este estudo busca apresentar os aspectos históricos e operacionais desses sistemas, discutindo os desafios para o Brasil. Os modelos internacionais se espelham no exemplo americano, pioneiro nesse processo. No Brasil, diversas iniciativas foram e estão sendo estabelecidas, entretanto, não temos um pleno sistema nacional de informação sobre IRAS, o que aponta a necessidade de reconhecer estratégias em vigência, fortalecendo o Estado como elo de comunicação; buscando um plano nacional para a formação de equipes de vigilância com aparato tecnológico necessário, e discutindo a atualização das legislações que já não contemplam os desafios atuais de tais ocorrências. Essas são medidas essenciais no contexto brasileiro para a vigilância unificada de IRAS, almejando segurança e qualidade nos cuidados em saúde.

Infecção Hospitalar; Controle de Infecções; Vigilância Epidemiológica; Sistemas de Informação 


\section{Introduction}

Practices in the prevention and control of healthcare-associated infections (HAI) are recent. Major strides in this area resulted from the pioneering work of Florence Nightingale and Ignaz Semmelweiss in the 19th century and the subsequent discoveries and progress of microbiology 1,2.

Over the years, this trend focused increasingly on HAI, raising awareness of the increase in the incidence of such infections worldwide, in addition to highlighting them as a preventable situation and an unwanted result of healthcare, thus making them a serious major public health problem $3,4,5$.

Given this scenario, it is extremely important to identify the determinants and risk factors related to such infections through active search in critical or problematic areas in various healthcare services in order to help characterize their epidemiological profile and thus allow planning and implementing measures for their prevention and control. Tools from epidemiology and microbiology, linked to information systems, have become an essential mechanism in various countries of the world that seek practices for which case-resolution capacity can be evaluated.

In the hospital setting, HAI surveillance systems have been developed for at least three decades in various regions of the world, while other regions lack even a minimum infrastructure for guaranteeing basic hygiene during provision of care 6,7. This scenario is mirrored at the government level: while some countries have already developed advanced surveillance systems, others ignore them entirely. The creation of HAI surveillance systems at the government level is rather recent and is still being implemented around the world and particularly in Brazil.

The current study thus aimed to conduct a narrative review of government HAI epidemiological surveillance. We opted to characterize HAI epidemiological surveillance systems from selected countries, focusing on the historical process of their development and their main functional characteristics. The selection of these countries was based on the current study authors' perception that they have produced government models for HAI epidemiological surveillance systems. The study is expected to contribute to the discussion on the main challenges in promoting a unified, efficient, and effective Brazilian system.

\section{Methods}

\section{Study design}

This study was a narrative literature review. Information was collected by consulting government agency websites from the selected countries, which the authors defined as having a tradition in HAI prevention and control. We also consulted technical documents published by these agencies. We only selected documents with a relevant approach to HAI surveillance systems. The choice of the gray literature was due to the study's object, given that the required information is not always published in indexed journals. However, we also incorporated a search for cross references from periodicals, based on citations from the above-mentioned documents. The search was conducted from January 2011 to January 2013. Three researchers conducted the website search and downloaded and selected the articles (C.N.J., D.S.M., and M.C.P.).

\section{Inclusion and exclusion criteria}

Selection of these countries was based on the perception and recognition that they are models for HAI epidemiological surveillance [USA, through the website of the Centers for Disease Control and Prevention - CDC (http://www. cdc.gov/nhsn); European countries: Germany, France, Netherlands, through consultation of the website of the European Center for Disease Prevention and Control - ECDC (http://www.ecdc. europa.eu/en/Pages/home.aspx); and for South America, the websites of the National Institute of Epidemiology of Argentina (http://www.vihda. gov.ar), the National Institute of Health of Colombia (http://www.ins.gov.co/iaas/Paginas/quees-la-RED-PREVINS.aspx), the Ministry of Health of Chile (http://www.minsal.gob.cl/portal/url/ page/minsalcl/g_problemas/g_infeccionesin trahospitalarias/infeccionesintra_home.html), and the Ministry of Public Health of Uruguay (http://www.msp.gub.uy/imgnoticias/11087.pdf). We initially sought to identify countries on the different continents whose output in the scientific media (periodicals and congress meetings) demonstrated a certain level of organizational structure; this stage provided the point of departure for a detailed search of government agency websites. Exclusion criteria for the study were websites or documents that failed to contain or provide clear information on the study's object of interest. 


\section{Selected variables and data analysis}

On each website, we identified the historical process in the formation of the surveillance system and the principal characteristics of its functioning, such as: reporting periodicity, data transfer methods, inclusion criteria for participation by health institutions, voluntary nature of participation, and surveillance components. This information was later cross-referenced with other bibliographic lists in order to complement the respective knowledge and capture the trend in this process in the world context.

The principal characteristics of these systems were grouped, based on an analysis of this historical process and technical characteristics, thus contributing to the discussion of these issues in developing a unified system for Brazil.

\section{History of government HAl surveillance systems in the world}

The epidemiological approach to infectious diseases in the hospital setting dates to the early $19^{\text {th }}$ century, even before the germ theory of disease. Florence Nightingale played a famous role in this scenario during the Crimean War, when she conducted control measures aimed at reducing such diseases and monitoring infection and mortality in English soldiers, using statistics 2. Since then, over the decades, and added to evolution in microbiology, pharmacology, and healthcare technologies, monitoring this phenomenon was stepped up and became increasingly relevant, to the point of being incorporated by hospitals worldwide 6 .

When such practices were still in the initial implementation, based on limited awareness of the phenomenon as a public health threat, no government action was taken to monitor HAI. The first reports from population studies that sought to identify the situation with HAI began in the late 1960s. The process stepped up in the early 1970s, with a significant increase in the 1990s.

The basis for these initial studies was the search for data reflecting the real context in which HAI occurs, an apparently serious situation, but in fact with limited data. Thus, having objective information, various countries would obtain backing for new practices to be planned in order to minimize or even eliminate the problem.

Based on these preliminary studies, the first surveillance systems were developed, aimed not merely at immediate knowledge of the phenomenon, but rather at its constant and global follow-up through permanent monitoring of populations.
The initial reference for these studies appeared in the 1970s in the United States, through the CDC, which was seeking to evaluate HAI in the country and organized the National Nosocomial Infection Study, the first major study on HAI in the world. This initial study included 70 hospitals and sought to identify trends in rates, the most heavily affected areas, and microbial resistance, but still lacking precision in the results $8,9,10$.

Along this line, from 1970 to 1974 the CDC also launched the Study on the Efficacy of Nosocomial Infection Control (SENIC), a project with three basic objectives: identify surveillance programs and their relationship to the reduction of infection rates; estimate the magnitude of HAI; and detect relations between programs, services, and patients for the prevention and control of these infections. The study concluded that effective surveillance programs reduce infection rates by $30 \%$, thus calling attention to the importance of surveillance programs for prevention and control 8,9,10.

In 1986, these results provided the basis for creating the first HAI surveillance network in the world, the National Nosocomial Infection Surveillance System (NNIS), which has improved over the years and is currently incorporated into the National Healthcare Safety Network (NHSN) $8,10,11,12,13$.

Since then, the United States has continued to take a leading role in this process, and the project gained strength over the years, becoming the reference for the majority of surveillance networks created subsequently in other countries.

In the 1970s, Europe also began to focus on monitoring HAI, following the North American example. The 1st European Council expressed the concern on the part of European countries in relation to the surveillance and control of these infections. Since then, studies began to be developed in various regions of the European continent, providing data in some countries and forming an initial structure for networks that were still fragmented and individualized, and thus still suffering from problems with unification and standardization in various contexts 14,15,16,17.

After years of study in this context, the member countries of the European Union, funded by their own budgets and encouraged by the World Health Organization (WHO) and other regional agencies, decided to launch a single HAI surveillance network for the continent, namely the project entitled Hospital in Europe Link for Infection Control through Surveillance (HELICS) 14,15,16,17.

The project began in 1995 with phase I (harmonized approach to HAI surveillance in surgery and ICU), and thus far four other phases have 
been planned (phase II - implementation of an HAI network with an association between surveillance, control, training, and research; phases III and IV - implementation of projects from phases I and II, respectively), which are still in the process of structuring and implementation. Important results include the establishment of surveillance protocols for the entire European region towards a unified network for HAI prevention and control 14,15,16,17.

In addition to the HELICS network, other European countries developed well-structured HAI surveillance systems, with important gains in HAI prevention and control, such as the Netherlands, UK, and Germany, setting up their own networks in 1996.

The Netherlands and UK formed large-scale studies in the 1980s and early 1990s toward the development of their national networks for HAI control and prevention: the Preventie van Ziekenhuisinfecties door Surveillance (PREZIES) in the Netherlands and the Nosocomial Infection National Surveillance Scheme (NINSS) in the UK 18,19 .

Germany also formed its HAI surveillance system during the same decade, the Krankenhaus Infektions Surveillance System (KISS). Unlike the others, this network was designed without population-based studies, but rather on the basis of microbiology studies. Epidemiology was incorporated later 20 .

South America already provides good examples of HAI surveillance systems. One such system is the National Program for the Surveillance of Hospital Infections in Argentina (VIHDA). This official initiative by the Argentine Ministry of Health was launched in 2004 based on studies from the late 1990s and early 2000s, promoting the development of specific software for this purpose 21 .

Chile, Uruguay, and Colombia have also launched successful programs. Chile has had a national program for HAI surveillance since 1982 and has been organizing a national data network. Uruguay set up its national HAI surveillance system in 2006 and already presents biannual nationwide data. Colombia signed an agreement between various government agencies in 2010 to implement PREVINS (National Network for the Prevention, Surveillance, and Control of Healthcare-Associated Infections) 22,23,24.

This history also includes some regional surveillance systems, such as the well-structured Victorian Nosocomial Infections Surveillance Systems (VICNISS) in Australia Although limited to HAI surveillance in only one region of the country, the system is functional and well-developed and produces important results, structured on the basis of studies in the 1990s and effectively implemented since 199925.

Many of these systems stemmed from large prevalence studies on such infections. Thus, the establishment of HAI surveillance is a recent international phenomenon.

\section{Operational aspects of HAl surveillance systems around the world}

HAI surveillance systems in various regions or countries are information mechanisms that collect, transfer, and analyze data. These data are collected by health services through surveillance modules with various components, such as monitoring infections associated with devices and/or procedures, process indicators, monitoring pathogens, issues related to health workers' safety, and others. These data are transferred between levels of government until reaching the central agency that processes and stores them and feeds the results back to the system to orient activities in evaluation and improvements in the control and prevention of such infections 10,20,26.

The main characteristics of the existing systems around the world include some features that allow health institutions to choose the data they wish to monitor, incorporating so-called surveillance modules 10,20,26. Participation by institutions in the systems is usually voluntary 21,27 , and in some cases it is only mandatory for the surveillance of certain infections 10. In the State of Victoria, Australia, for example, public hospitals are required to participate in the program, and since 2009 private hospitals may also participate on a voluntary basis, so that all the systems are generally fed by both public and private hospitals 26 . Data confidentiality is guaranteed by all the systems 10,27,28 (Table 1).

Development of the surveillance methodology (notification criteria) is based on the pioneering United States system, which served as a model for other systems 20,26,27. Data obtained by these system largely focus on incidence of HAI cases. In some situations they include monitoring process indicators and prevalence data. Participation time by health institutions varies among systems, according to the chosen surveillance module 10 (Table 1 ).

Data are generally transferred between government levels electronically $10,20,21,26$, but there are exceptional situations. For example, VICNISS allows sending data in other ways, including print format 25 . The periodicity of data transfer also varies between systems, with monthly collection as the most common approach. 
Table 1

Summary of operational characteristics of surveillance systems for healthcare-associated infections (HAI) in selected countries.

\begin{tabular}{|c|c|c|c|c|}
\hline Surveillance system & Location & Surveillance strategies & $\begin{array}{c}\text { Mode of } \\
\text { participation }\end{array}$ & Surveillance systems' websites \\
\hline $\begin{array}{l}\text { National Nosocomial } \\
\text { Infections Surveillance } \\
\text { (NNIS)/National Healthcare } \\
\text { Safety Network (NHSN) }\end{array}$ & $\begin{array}{l}\text { United } \\
\text { States }\end{array}$ & $\begin{array}{l}4 \text { components: (i) patient safety (5 } \\
\text { modules: surveillance of devices, } \\
\text { surveillance of procedures, surveillance of } \\
\text { medicines, multiresistant microorganisms, } \\
\text { vaccination); (ii) health workers' safety; } \\
\text { (iii) biosurveillance; (iv) research and } \\
\text { development }\end{array}$ & $\begin{array}{l}\text { Voluntary, } \\
\text { mandatory in } \\
\text { some States }\end{array}$ & http://www.cdc.gov/nhsn/ \\
\hline $\begin{array}{l}\text { Hospital In Europe Link for } \\
\text { Infection Control through } \\
\text { Surveillance (HELICS) }\end{array}$ & Europe & $\begin{array}{c}3 \text { priority surveillance targets: (i) ICU } \\
\text { infections in intensive care; (ii) infections } \\
\text { in surgical patients; (iii) prevalence studies } \\
\text { on HAl }\end{array}$ & Voluntary & http://helics.univ-lyon1.fr/home.htm \\
\hline $\begin{array}{l}\text { Preventie van } \\
\text { Ziekenhuisinfecties door } \\
\text { Surveillance (PREZIES) }\end{array}$ & Netherlands & $\begin{array}{c}5 \text { surveillance modules, four of which for } \\
\text { incidence studies (post-op infections, } \\
\text { surgical wound infections in post-cardiac } \\
\text { surgery patients, sepsis, and ventilator- } \\
\text { associated pneumonia) and one module for } \\
\text { prevalence studies }\end{array}$ & Voluntary & http://www.prezies.nl/ \\
\hline $\begin{array}{l}\text { Krankenhaus Infektions } \\
\text { Surveillance System (KISS) }\end{array}$ & Germany & $\begin{array}{l}9 \text { surveillance components: (i) ICU patients } \\
\text { (ITS-KISS); (ii) surgical patients (OP-KISS); } \\
\text { (iii) premature infants in neonatal intensive } \\
\text { care units (NEO-KISS); (iv) bone marrow } \\
\text { transplant patients (ONKO-KISS); (v) } \\
\text { outpatients (AMBU-KISS); (vi) patients } \\
\text { with specific invasive procedures -central } \\
\text { venous catheters, mechanical ventilation - } \\
\text { in non-intensive care units (KISS-DEVICE); } \\
\text { (vii) hand hygiene with alcohol-based } \\
\text { solutions (HAND-KISS); (viii) Clostridium } \\
\text { difficile- associated diseases (CDAD-KISS); } \\
\text { (ix) methicillin-resistant Staphylococcus } \\
\text { aureus (MRSA-KISS) }\end{array}$ & Voluntary & $\begin{array}{l}\text { http://www.nrz-hygiene.de/ } \\
\text { surveillance/kiss/ }\end{array}$ \\
\hline $\begin{array}{l}\text { Surveillance of Hospital } \\
\text { Infections, Argentina } \\
\text { (VIHDA) }\end{array}$ & Argentina & $\begin{array}{l}3 \text { surveillance components: (i) institutional } \\
\text { diagnosis; (ii) surveillance of critical and } \\
\text { surgical areas; (iii) prevalence studies }\end{array}$ & Voluntary & http://www.vihda.gov.ar/ \\
\hline $\begin{array}{l}\text { Victorian Nosocomial } \\
\text { Infections Surveillance } \\
\text { Systems (VICNISS) }\end{array}$ & $\begin{array}{l}\text { State of } \\
\text { Victoria, } \\
\text { Australia }\end{array}$ & $\begin{array}{l}2 \text { surveillance methods: (i) type 1, large } \\
\text { hospitals, with } 7 \text { modules: surgical site } \\
\text { infections, intensive care, neonatal } \\
\text { intensive care, antibiotic prophylaxis in } \\
\text { surgery, incidence in hemodialysis, S. } \\
\text { aureus bacteremia, C. difficile infections; } \\
\text { (ii) type 2, small hospitals, with } 3 \text { modules: } \\
\text { process indicators, surgical site infections, } \\
\text { and infections related to selected events }\end{array}$ & $\begin{array}{l}\text { Mandatory in } \\
\text { public hospitals }\end{array}$ & http://www.vicniss.org.au/ \\
\hline
\end{tabular}

Some systems validate the incoming data 27,28 . Validation methods range from verification of data consistency through review of electronic forms or files to verification of the logical sequence of dates and genders for certain procedures 27 . Some systems periodically visit the reporting institutions as a way of validating the notification process 27,28 . 
Participating institutions generally have access to their own databank 27,28 as a form of feedback. Results from the data can be generated by the service itself at any time 21,27 or are sent periodically by the system in a general compilation that provides parameters for comparison with other institutions 26,27 .

\section{Challenges for the HAl epidemiological surveillance system in Brazil}

In Brazil, as in other countries of South America, regulation and real concern over HAI control and prevention appeared in the late 1970s and early 1980s. This period was marked by the phenomenon's visibility in the national scenario, emphasized by the media, highlighting it as a serious problem in healthcare services $3,4,5$.

This context impelled the Brazilian government to plan and implement measures based mainly on legislation and that began to include guidelines for HAI control and prevention in healthcare workers' daily practice. However, as elsewhere, such actions were based on the presumed occurrence of HAI, while in fact no concrete data existed on the country's real situation $3,4,5$.

This troublesome position, along with an emerging international trend, raised concern among Brazilian health authorities over surveillance of this phenomenon; measures were thus launched, but only a decade after passage of the first specific legislation on the issue.

The main reference and the only major Brazilian study on HAI prevalence appeared in 1994. This study identified high rates of such infections (rate of patients with HAI: $13.1 \%$; HAI rates by topography: respiratory $28.9 \%$, surgical $15.6 \%$, skin $15.5 \%$, and urinary $11 \%$ ), confirming the prior assumption 29 . However, this was a localized study that included 99 hospitals in State capitals and that worked with the Brazilian Unified National Health System (SUS), and the results failed to translate into the creation of a unified national system.

When the National Health Surveillance Agency (ANVISA) was created, government action for the control of infections was one of its responsibilities. However, unlike other communicable diseases, which are considered public health problems, HAI do not come under the aegis of the National Epidemiological Surveillance System of the Health Surveillance Secretariat/Ministry of Health. ANVISA entered this context during a time when there were few Brazilian studies on this theme, in addition to various other problems with HAI surveillance in the country, such as the lack of Hospital Infection Control Committees, scarcity of qualified human resources, lack of definition of notification criteria, and others. This situation raised numerous barriers to the formation of a properly functioning nationwide surveillance system 30,31 .

Some projects established by ANVISA merit special attention, like the creation of the National Information System on the Control of Infections in Healthcare Services (SINAIS), software developed and distributed by the agency in 2004 as a HAI surveillance tool. However, although the system was available for four years, there was little adherence to its use, and maintenance of the system eventually ceased 32 .

Other activities aimed at the collection of epidemiological data not specific to HAI surveillance were also launched to collaborate with this monitoring. These included the RM Network (National Network for Monitoring Microbial Resistance in Health Services) and the National Network for the Investigation of Outbreaks and Adverse Events in Health Services (RENISS). However, as of the writing of this article (February 2013), the Microbial Resistance Network is inactive and RENISS only operates on an irregular basis 33,34 . Together, these initiatives formed the principal group of Brazilian national attempts to standardize HAI surveillance in the country.

Regional projects have also received emphasis for their surveillance systems implemented to respond to the lack of an efficiently unified national system. São Paulo was the pioneering State in this process, through its Division of Hospital Infection at the Center for Epidemiological Surveillance, establishing a formally developed and functional structure for HAI surveillance 35 . The State of Paraná, through its Health Services Sanitary Division, developed specific software to obtain online information on these infections 36 .

ANVISA is currently preparing manuals on different issues in this public health problem, discussing indicators and preventive measures and strategies, besides information on the principal healthcare-related infectious syndromes in the attempt to standardize criteria and encourage prevention. Under the current HAI epidemiological surveillance model, notification to the Federal agency is designed through an online form called FormSUS 37. Thus far, the principal focus has been primary bloodstream infections 38 .

Despite these strategies to unify national data, the different States are autonomous in this process and can therefore establish independent data collection models, thus favoring variation between standardized instruments for this purpose. 
The national HAI database is still scanty and lacks interface with other health information systems. The Brazilian government clearly intends to unify the flow and form of notification through the definition of national indicators and modes of data transmission with the FormSUS, but this process still suffers limitations 37 .

The lack of clinical and epidemiological data on HAI furnished by current systems in Brazilian healthcare makes this situation worrisome in relation to planning various actions ${ }^{39}$. Seeking national parameters for HAI prevention is definitely an indispensable measure. However, there is still the need for a specific national system that integrates the data in order to reveal the real magnitude of the problem in the country.

The challenge for the consolidation of this national surveillance system is huge. It is necessary to integrate currently successful models with incipient State-level systems in order to build a single system, without the need for duplicate data feeds (to the State and Federal levels).

The currently prevailing FormSUS, although somewhat useful for achieving advances in this area, is a provisional and preliminary situation, displaying inherent limitations in the project, since it was not meant to become a system, but a tool to support data transfer. In addition, its relationship to the regional models is not clear, and it functions separately, with no direct interface to the State-level data.

The main challenge is to establish dialogue between the existing State systems and the Federal system. Some State models work autonomously in relation to FormSUS. This situation generates duplicate work between spheres of government and hinders the strengthening of actions based on real data.

Brazil is a country with continental dimensions in which States use different data collection models for HAI. The States play an essential role in this process, since they provide the main link between the Federal and local governments, serving as a strategic communications channel. Thus, strengthening the State's role, valuing and actively including it in the system's development, besides negotiating outcome targets, can make a first step in this direction.

Another challenge is to train and organize HAI surveillance teams. Hospitals are legally required to establish hospital infection control committees, but some services fail to set up such teams while others merely do so to comply with the legislation, with insufficiently trained teams, often overloaded with tasks other than HAI surveillance 40,41 .
This reality results partially from deficient standardization and lack of systematic audits. The legislation leaves gaps in these teams in terms of minimal training for managing epidemiological data and planning actions. We also lack knowledge on the real national situation with the workforce dedicated to HAI. There are important regional differences, which makes it particularly difficult to propose the ideal human resources for developing a national system 40,41 .

Nevertheless, training these teams does not suffice. Structural support is needed with equipment, software, and other information technologies for this training process. It is indispensable to prepare the various surveillance teams in order for all the realities to interconnect in a streamlined and solid way in permanent monitoring. However, the reality of healthcare services in many places is very different from this process, leading us to reflect on the possibility of a national plan pursuing this target by improving the technological park for information in healthcare services 42 .

Studies are also needed to furnish a precise diagnosis of the characteristics of infection control services in Brazil. This diagnosis is essential for orienting and implementing a national HAI surveillance system, respecting the different levels of healthcare services' development in the country's various regions.

Data from this surveillance need to be generated, analyzed, and published urgently in order for approaches to be planned systematically. It is imperative to establish actions based on real Brazilian information and not only on international data. The country has its specificities, and continuous monitoring of HAI is a strategic requisite for prevention.

In summary, it is necessary and urgent to link the various government levels to promote an integrated information system; it is essential to promote training in epidemiological surveillance; it is strategic to develop incentives to improve the infrastructure to develop the work process in surveillance teams, and to contribute to strategies for the formation of systems in order to actually prevent and control HAI.

All these planned proposals in the search for a national HAI surveillance system should be factors that allow allocating this phenomenon within the scope of health policies in a country that effectively pursues quality in healthcare. 


\section{Resumen}

La formación de los sistemas de vigilancia de infecciones asociadas a la atención en salud (IAAS) es una medida esencial para la planificación de acciones de prevención y control. Algunos modelos importantes en el mundo se están desplegando en las últimas décadas. Este estudio analiza los aspectos históricos y operativos de estos sistemas, discutiendo los desafíos para Brasil. Los modelos internacionales se reflejan en el ejemplo norteamericano, pionero en este proceso. En Brasil varias iniciativas han sido y están siendo establecidas, sin embargo, no se dispone de un pleno sistema nacional de información sobre IAAS, señalando la necesidad de reconocer estrategias vigentes; así como el fortalecimiento del Estado como un enlace de comunicación, buscando un plan nacional para formar equipos de vigilancia con los aparatos tecnológicos necesarios, asi como discutiendo la actualización de las leyes que ya no incluyen los desafíos actuales para este tipo de ocurrencias. Estos son pasos esenciales en el contexto brasileño para el control unificado de las IAAS con los objetivos de seguridad y calidad en el cuidado de la salud.

Infección Hospitalaria; Control de Infecciones;

Vigilancia Epidemiológica; Sistemas de Información

\section{Contributors}

C. Nogueira Junior and D. S. Mello contributed to the study conceptualization and design, data collection, analysis, and interpretation, and writing of the manuscript. M. C. Padoveze contributed to the data collection, analysis and interpretation, and writing of the manuscript. I. Boszczowski, R. A. Lacerda and A. S. Levin conducted a critical revision of the manuscript and approved the final version.

\section{Acknowledgments}

The authors wish to thank the School of Nursing at the University of São Paulo and FAPESP that financed and subsididized this study under process number 2012/02700-7, with dispatch issued on May 9, 2012.

\section{References}

1. Pittet D, Boyce JM. Hand hygiene and patient care: pursuing the Semmelweis legacy. Lancet Infect Dis 2001; 1:9-20.

2. Gill CJ, Gill GC. Nightingale in Scutari: her legacy reexamined. Clin Infect Dis 2005; 40:1799-805.

3. Lacerda RA, Jouclas VMG, Egry EY. Infecções hospitalares no Brasil. Ações governamentais para o seu controle enquanto expressão de políticas sociais na área de saúde. Rev Esc Enferm USP 1996; 30:93-115.

4. Lacerda RA, Egry EY. As infecções hospitalares e sua relação com o desenvolvimento da assistência hospitalar: reflexões para a análise de suas práticas atuais de controle. Rev Latinoam Enferm 1997; 5:13-23.
5. Lacerda RA. Produção científica sobre infecção hospitalar e a contribuição da enfermagem: ontem, hoje e perspectivas. Rev Latinoam Enferm 2002; 10:55-63.

6. Allegranzi B, Bagheri Nejad S, Combescure C, Graafmans W, Attar H, Donaldson L, et al. Burden of endemic health-care-associated infection in developing countries: systematic review and metaanalysis. Lancet 2011; 377:228-41.

7. Ganatra HA, Zaidi AK. Neonatal infections in the developing world. Semin Perinatol 2010; 34: 416-25. 
8. Haley RW, Quade D, Freeman HE, Bennett JV. Study on the efficacy of nosocomial infection control (Senic Project): summary of study design. Am J Epidemiol 1980; 111:472-85.

9. Garner JS, Jarvis WR, Emori TG, Horan TC, Hughes JM. CDC definitions for nosocomial infections 1988. Am J Infect Control 1988; 16:128-40.

10. Centers for Disease Control and Prevention. National Healthcare Safety Network. http://www.cdc. gov/nhsn (accessed on 12/Jan/2013).

11. Horan TC, Gaynes RP, Martone WJ, Jarvis WR, Emori TG. CDC definitions of nosocomial surgical site infections, 1992: a modification of CDC definitions of surgical wound infections. Am J Infect Control 1992; 20:271-4.

12. Edwards JR, Peterson KD, Andrus ML, Dudeck MA, Pollock DA, Horan TC. National Healthcare Safety Network (NHSN) report, data summary for 2006, issued June 2007. Am J Infect Control 2007; 35: 290-301.

13. Centers for Disease Control and Prevention. Final record of the proceedings. external peer review of the division of healthcare quality promotion surveillance branch. Atlanta: Centers for Disease Control and Prevention; 2008.

14. Mertens R, Van Den Berg JM, Fabry J, Jepsen OB. Helics: a European project to standardise the surveillance of hospital acquired infection, 19941995. Euro Surveill 1996; 1(4):154. http://www.eu rosurveillance.org/viewarticle.aspx?articleid=154.

15. Hospital in Europe Link for Infection Control through Surveillance. Helics I report - final report. http://helics.univ-lyon1.fr/report/helics1/he lics1_report.pdf (accessed on 21/Jul/2011).

16. Hospital in Europe Link for Infection Control Through Surveillance. Helics II report - preliminary report. http://helics.univ-lyon1.fr/report/he lics2/report.pdf (accessed on 21/Jul/2011).

17. Hospital in Europe Link for Infection Control Through Surveillance. Supported by the European Union Directorate General Sanco Grant Agreement. http://helics.univ-lyon1.fr/helicshome.htm (accessed on 25/Jan/2013).

18. Coello R, Gastmeier P, De Boer A. Surveillance of hospital-acquired infection in England, Germany, and the Netherlands: will international comparison of rates be possible? Infect Control Hosp Epidemiol 2001; 22:393-7.

19. Prezies National Network for the Surveillance of Nosocomial Infections. Rijksinstituut voor Volksgezondheid en Milieu, Centraal Begeleidingsorgaan, Utrecht, Netherlands. http://www.prezies. $\mathrm{nl} / \mathrm{zkh} /$ index.html (accessed on 11/Jan/2013).

20. Nationales Referenzzentrum für Surveillance von Nosokomialen Infektionen. Protocol healthcareassociated infection and multidrug-resistant organism surveillance on intensive care units. http://www.nrz-hygiene.de/en/surveillance/ hospital-infection-surveillance-system/its-kiss/ 2fa80876/633/734 (accessed on 30/Aug/2011).
21. Instituto Nacional de Epidemiología “Dr. Juan H Jara". Programa Nacional de Vigilancia de Infecciones Hospitalarias de Argentina (VIHDA). http:// www.vihda.gov.ar/ (accessed on 03/Feb/2012).

22. Ministerio de la Salud. Infecciones intrahospitalarias y asociadas a la atención en salud. http://www. minsal.gob.cl/portal/url/page/minsalcl/g_pro blemas/g_infeccionesintrahospitalarias/infeccionesintra_home.html (accessed on 28/Jan/2013).

23. Instituto Nacional de Salud. Qué es la RED PREVINS? http://www.ins.gov.co/iaas/Paginas/que-esla-RED-PREVINS.aspx (accessed on 28/Jan/2013).

24. Ministerio de la Salud Pública. Sistema nacional de vigilancia de infecciones hospitalarias. http:// www.msp.gub.uy/imgnoticias/11087.pdf (accessed on $28 / \operatorname{Jan} / 2013$ )

25. Victorian Government. Vicniss healthcare associated infection surveillance. http://www.vicniss. org.au/default.aspx (accessed on 30/Aug/2013).

26. Department of Health, Victorian Government. Vicniss hospital-acquired infection surveillance: annual report 2009-10. http://www.health.vic. gov.au/infectionprevention (accessed on 08/ Aug/2011).

27. Manniën J, Van Der Zeeuw AE, Wille JC, Van Den Hof S. Validation of surgical site infection surveillance in the Netherlands. Infect Control Hosp Epidemiol 2007; 28:36-41.

28. Russo PL, Bull A, Bennett N, Boardman C, Burrell $\mathrm{S}$, Motley J, et al. The establishment of a state-wide surveillance program for hospital-acquired infections in large Victorian public hospitals: a report from the VICNISS Coordinating Centre. Am J Infect Control 2006; 34:430-6.

29. Prade SS, Oliveira ST, Rodriguez R, Nunes FA, Netto EM, Pereira M, et al. Estudo brasileiro da magnitude das infecções hospitalares em hospitais terciários. Revista do Controle de Infecção Hospitalar 1995; 2:11-24.

30. Agência Nacional de Vigilância Sanitária. Anvisa intensifica controle de infecção em serviços de saúde. Rev Saúde Pública 2004; 38:475-8.

31. Santos AAM, Lopes FFP, Cardoso MRA, Serufo JC. Diagnóstico do controle da infecção hospitalar no Brasil. Programa de pesquisas hospitalares em busca de excelência: fortalecendo o desempenho hospitalar no brasil. Brasília: Agência Nacional de Vigilância Sanitária/Banco Mundial; 2005.

32. Agência Nacional de Vigilância Sanitária. Anvisa suspende a manutenção do Sistemas Sinais. http:// www.anvisa.gov.br/divulga/informes/2009/ 220509.htm (accessed on 12/Aug/2011).

33. Agência Nacional de Vigilância Sanitária. Rede Nacional de Monitoramento da Resistência Microbiana em Serviços de Saúde - Rede RM. http:// www.anvisa.gov.br/servicosaude/controle/rede rm/index.htm (accessed on 20/Jan/2013). 
34. Agência Nacional de Vigilância Sanitária. Rede Nacional Para Investigação de Surtos e Eventos Adversos em Serviços de Saúde (Reniss). http://www. anvisa.gov.br/servicosaude/controle/reniss.htm (accessed on 20/Jan/2013).

35. Divisão de Infecção Hospitalar, Centro de Vigilância Epidemiológica "Professor Alexandre Vranjac", Secretaria de Estado da Saúde de São Paulo. http:/ / www.cve.saude.sp.gov.br/ (accessed on 20/Jan/ 2013).

36. Secretaria de Estado da Saúde do Paraná. Vigilância sanitária. http://www.sesa.pr.gov.br/modules/ conteudo/conteudo.php?conteudo=2796 (accessed on 12/Feb/2013).

37. Agência Nacional de Vigilância Sanitária. http:// portal.anvisa.gov.br/wps/portal/anvisa/home (accessed on 20/Jan/2013).

38. Agência Nacional de Vigilância Sanitária. Indicadores nacionais de infecções relacionadas à assistência à saúde. Manual. http://www.saude.mt.gov. $\mathrm{br} /$ portal/controle-infeccoes/documento/apre sentacao/arquivos\%20a\%20anexar/indicadores_ nacionais_de_iras_set_2010_anvisa.pdf (accessed on 14/Aug/2011).
39. Prade SS, Vasconcellos MM. Identificando fontes de dados nos sistemas de informações do SUS para a vigilância epidemiológica das IH. Inf Epidemiol SUS 2001; 10:121-8.

40. Fontana RT, Lautert L. Aspectos ético-legais do controle da infecção hospitalar: algumas reflexões relativas ao enfermeiro. Ciênc Cuid Saúde 2008; 7:546-50.

41. Alves DCI, Évora VDM. Questões éticas envolvidas na prática profissional de enfermeiros da Comissão de Controle de Infecção Hospitalar. Rev Latinoam Enferm 2002; 10:265-75.

42. Moraes I, Gómez M. Informação e informática em saúde: caleidoscópio contemporâneo da saúde. Ciênc Saúde Coletiva 2007; 12:553-64.

Submitted on $01 /$ Mar/2013

Final version resubmitted on 20/Jun/2013

Approved on 01/Aug/2013 